\title{
Mathematical modeling of an air split-conditioner heat pump operation for investigation its exergetic efficiency
}

\author{
Labay V. Yo., Yaroslav V. Yu., Dovbush O. M., Tsizda A. Ye. \\ Department of Heat, Gas Supply and Ventilation, \\ Institute of Construction and Engineering Systems, \\ Lviv Polytechnic National University, \\ 12 S. Bandera Str., 79013, Lviv, Ukraine
}

(Received 20 November 2019; Revised 3 May 2020; Accepted 5 May 2020)

\begin{abstract}
In the modern technologies related to energy transformation, namely in the field of heat pumps of air split-conditioners ("air-to-air"), an important place is occupied by apparatuses and processes, which energy perfection can be objectively evaluated only on the basis of analysis of their exergy efficiency. This allowed substantiating the actuality of the research task due to insufficient information on the exergy efficiency of the use of heat pumps of air split-conditioners and their elements. The author's innovation mathematical model for the analysis of the operation of one-step freon heat pumps, which are used in air splitconditioners, according to the exergetic method, is developed. In this article analyzes the exergetic output-input ratio (OIR) and the losses of exergy in the separate elements of heat pumps of air split-conditioners on the example heat pumps of air split-conditioners with a nominal heating capacity of $2500,2840,3580,5620,6400 \mathrm{~W}$ by "Daikin" firm in the standard external temperature conditions on the refrigerant R410A are obtained on this model. It has been determined that, by exergy efficiency, heat pumps of air splitconditioners with higher heat capacity have lower exergy efficiency. In our opinion, this is due to the incorrect acceptance of air flow rates on the evaporator and condenser, which do not correspond to the heat balances of these apparatuses and the same internal temperature regime for different heat capacity heat pumps of air split-conditioners. An example is the Grassman's diagram of the heat pump of air split-conditioner with the heat capacity of $2500 \mathrm{~W}$. The losses of exergy having been established in all elements of heat pumps of air split-conditioners indicate that the air split-conditioner parts should be improved to reduce the losses of exergy in them and to increase its exergetic OIR in general.
\end{abstract}

Keywords: heat pump of air split-conditioner, exergy balance, exergy efficiency, exergy losses.

2010 MSC: $80 \mathrm{~A} 10,80 \mathrm{~A} 20$

DOI: $10.23939 / \mathrm{mmc} 2020.01 .169$

\section{Introduction}

In the face of growing shortages and rising prices for fuel and energy resources, the problem of energy saving and the use of alternative energy sources to solve the problem of reducing energy consumption for the Ukrainian economy becomes very actually [1].

A significant reduction in the use of traditional organic energy sources for building heating is possible thanks to, for example, heat pumps (HP) ("air-to-air") of air split-conditioners, that use renewable energy. Today, the use of air split-conditioners heat pumps in building's heat supply systems is becoming more common [2-9]. This is due to the fact that, by consuming $1 \mathrm{~kW}$ of electricity, HP air split-conditioners can carry up to $5 \mathrm{~kW}$ of energy for heating the room air. The use of HP provides not only energy-saving but also environmental impact.

According to the World Energy Committee, by 2020, $75 \%$ of heat supply (municipal and industrial) in developed countries will be supplied by heat pumps. In the USA, more than $30 \%$ of residential homes are equipped with HP. 
Currently, for Ukraine the problem of saving energy resources is particularly relevant in conditions of the market economy, limited resources of primary energy commodities - oil and gas.

In recent decades both abroad and in Ukraine with the aim of saving energy resources, fundamental research in a number of industries and technologies from the standpoint of exergetic methodology have been conducted [7-18].

Exergy not only quantities energy of any kind but also allows estimation of its quality. It defines the convergence, suitability of energy for its technical use in any conditions.

Since exergy is the only measure of the workability, that is, the suitability of energy resources for the use, it enables us to objectively evaluate the energy resources of any kind. Consequently, exergy is some universal measure of the suitability of energy resources. And the exergetic balance, on the basis of which the volume of energy resources is set, indicates the possibility of increasing the OIR of the process.

In some leading European countries and in USA exergy analysis has been introduced as a mandatory component in the development of projects and plans of modernization of manufacturing.

Exergy analysis of HP allows to evaluate the capabilities of each element of HP and increase the efficiency of its work in general.

So, in order to be convinced of the energy efficiency of the use of air split-conditioners heat pumps, we also conducted analytical researches on the developed mathematical model of air split-conditioners heat pumps operation by exergetic method, for example, "Daikin" firm air split-conditioners heat pumps. Similar results could be obtained for any other air split-conditioner heat pump, of any other firm, and any other refrigerant. And this indicates the relevance of this research.

\section{Analysis of literature data and problem solving}

Successful application of the exergetic method of analysis of different technical systems, in particular of refrigerating machine of air split-conditioners, have been grounded in the works of R. K. Clausius, John V. Gibbs, G. Gouy, A. Stodola, J. Szargut, R. Petela, and V. M. Brodyansky for their technical and economic optimization and our works [7-18]. We have applied this method to the analysis of air split-conditioners heat pumps and have presented the results in this article. It is worth noting that exergetic valuation of the equipment is independent of the fluctuations of prices.

Modern air split-conditioners, which are used to create a suitable microclimate in small rooms, have achieved some definite technical improvement. As it is known, the energy efficiency of heat pumps of these air split-conditioners depends on parameters of both external and internal temperature conditions of their operation and type of refrigerant [8]. Therefore, to further improvement of efficiency of operation of air split-conditioners heat pumps, a detailed analysis of their functioning using different refrigerants (in particular R410A) is required.

For this purpose, based on the work [8], the innovative mathematical model of exergy analysis of the operation of air split-conditioners heat pumps has been developed by the authors, adapted for different refrigerants and manufacturers. This mathematical model makes it possible to carry out exergy investigations of heat pumps as a whole unit and of its individual parts, for obtaining full information about the processes of energy transformation that have a place in such systems [16-18]. The result of the analysis is to find the exergy OIR of the process in overall and the exergy losses in the individual elements of the air split-conditioner heat pump with the aim of its optimization.

So, based on the analysis of available literature data, decreasing the energy costs for air splitconditioners heat pumps can be achieved the most complete using the exergy analysis, which takes into account not only the quantity but also the quality of spent energy [16-18].

\section{Purpose and tasks of the investigation}

The purpose of this work is to determine the exergetic OIR and the exergy losses in the separate elements air split-conditioners heat pumps of firm "Daikin" on the two-component R410A refrigerant. 
To achieve this purpose, the following basic tasks have been formulated:

- to set the exergetic OIR on the example of air split-conditioners heat pumps with nominal heat capacity of 2500, 2840, 3580, 5620, $6400 \mathrm{~W}$ of firm "Daikin" at standard external temperature conditions on R410A refrigerant;

- to determine the exergy losses in separate elements of air split-conditioners heat pumps, for example, of firm "Daikin" with standard heating capacity of 2500, 2840, 3580, 5620, $6400 \mathrm{~W}$ on R410A refrigerant.

\section{Methods, materials and results of researches}

In this work, the object of the research is thermodynamic processes in air split-conditioners heat pumps for heating air of the room in CS (cold season), which are investigated on one-stage steam-compressor freon heat pump (without effective cooling of the compressor) that used for air split-conditioners, the scheme of which is shown in Fig. 1.

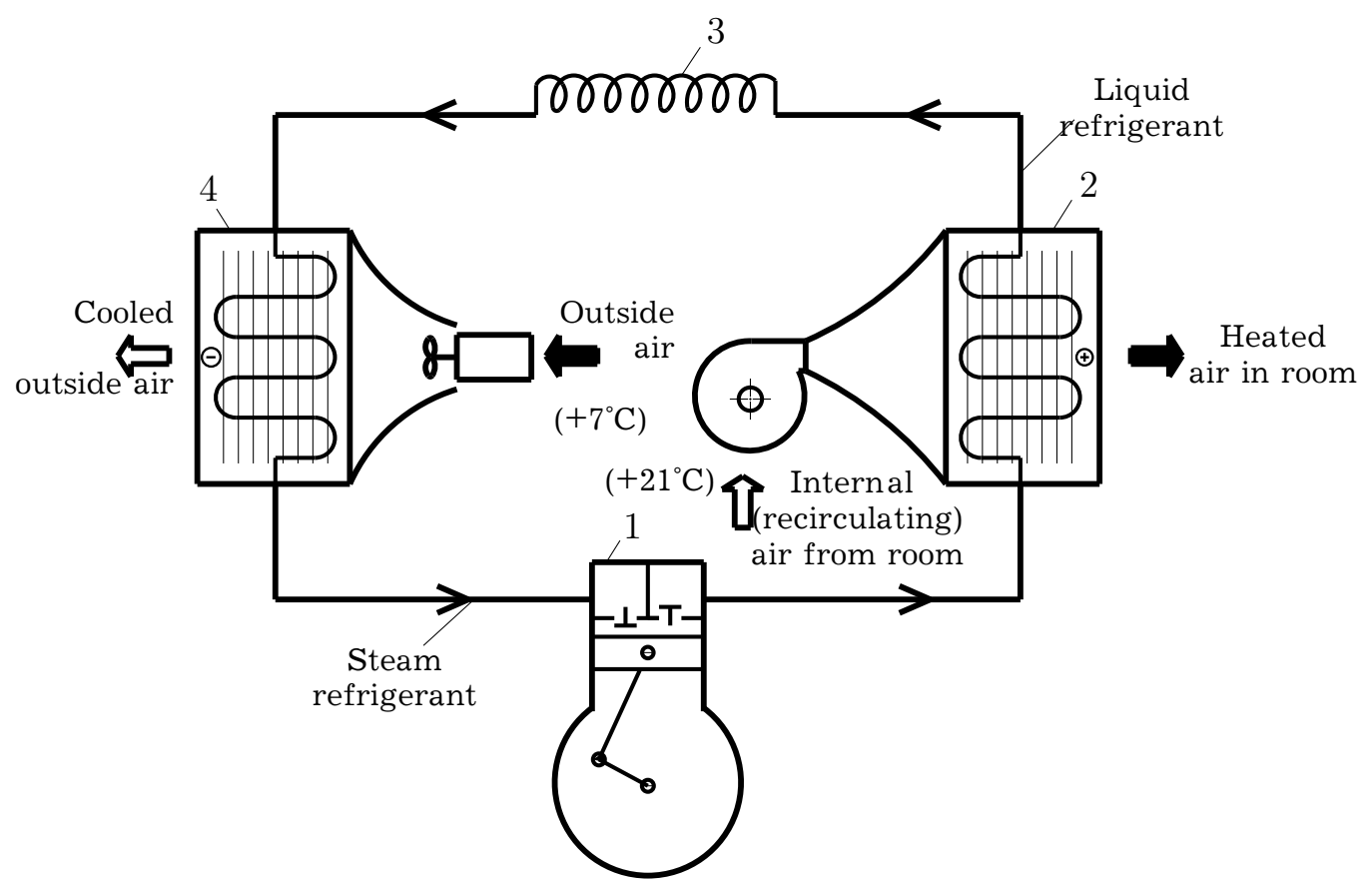

Fig. 1. Scheme of heat pump of air split-conditioner: 1 is compressor;

2 is condenser; 3 is capillary tube; 4 is evaporator.

The work of this heat pump is as follows. The heat from outside air (environment) is supplied to the liquid working refrigerant agent (RA) in the evaporator 4. As a result of heat supplying the working refrigerant boils in the evaporator 4 under the constant evaporation pressure $p_{0}=p_{e v}=p_{4}=p_{1^{\prime}}$ and evaporation temperature $t_{0}=t_{e v}=t_{4}=t_{1^{\prime}}$, and also overheats under pressure $p_{0}=p_{e v}=p_{1^{\prime}}=p_{1}$ from temperature $t_{e v}=t_{1^{\prime}}$ to suction temperature $t_{s u c}=t_{1}$. After that, the overheated steam from the evaporator 4 is sucked by the compressor 1 .

In compressor 1 , the overheated vapor of the working refrigerant is compressed from the evaporation pressure $p_{e v}=p_{1}$ to the condensation pressure $p_{\text {cond }}=p_{2}$ as the temperature increases from $t_{\text {suc }}=t_{1}$ pressure to $t_{2}$.

Due to friction, irreversible heat transfer and non-adiabatic, the real compression process 1-2 in compressor 1 does not coincide with isoentropic compression 1-2".

From the compressor 1, the overheated steam enters the condenser 2, where because of heat transfer to the internal (recirculation) air from the room, the overheated steam of the working refrigerant is 
cooled from the temperature $t_{2}$ to the condensation temperature $t_{\text {cond }}=t_{2^{\prime}}$, then the condensation of the RA vapor at constant condensation pressure $p_{\text {cond }}=p_{2^{\prime}}=p_{3^{\prime}}$ and the condensation temperature $t_{\text {cond }}=t_{2^{\prime}}=t_{3^{\prime}}$, liquid RA under pressure $p_{\text {cond }}=p_{3^{\prime}}=p_{3}$ from temperature $t_{\text {cond }}=t_{3^{\prime}}$ to temperature of overcooling $t_{\text {overcool }}=t_{3}$. During this time, the recirculation air in the condenser 2 is supplied to the room for heating.

After the condenser 2, the liquid refrigerant passes through the capillary tube (throttler) 3, where due to the throttling of the working refrigerant, the pressure falls from $p_{c o n d}=p_{3}$ to $p_{e v}=p_{4}$ and the temperature $t_{\text {cond }}=t_{3}$ decreases from to $t_{e v}=t_{4}$. During this the working RA partially evaporates $(\sim 20 \%)$. After the capillary tube 3 working RA enters again the evaporator 4 and the refrigeration cycle repeats again.

Technical characteristics of such air split-conditioners heat pumps, as usual, are pointed at the standard external temperature mode, which is determined by: standard temperature of surrounding environment (outside air) $t_{C 1}=+7^{\circ} \mathrm{C}$ (here the index " $C$ " is cool) and standard temperature of the conditioned internal (recirculation) air in a room $t_{H 1}=+21^{\circ} \mathrm{C}$ (here the index " $H$ " is heat).

For calculations of the standard heating process in air split-conditioner heat pump depicted on $(p, i)$-diagram at steady-state thermal condition of heat pump, when in the unit of time through each of its element (compressor, condenser, capillary tube and evaporator) a constant quantity of the refrigerant is circulating. Given values for calculating are: heating capacity $Q_{H}, \mathrm{~W}$, consumable power $N_{\text {in }}, \mathrm{W}$, amount of condensate on the evaporator $W_{\text {cond }}, l / h$, and internal temperature regime of heat pump of air split-conditioner, which in the occasion of work in a two-component RA, is characterized by four temperatures $t_{e v}, t_{\text {suc }}, t_{\text {cond }}, t_{\text {overcool }}$, which are determined by external temperature regime and air flows on the evaporator $L_{e v}, \mathrm{~m}^{3} / \mathrm{h}$, and the condenser $L_{c o n d}, \mathrm{~m}^{3} / \mathrm{h}$.

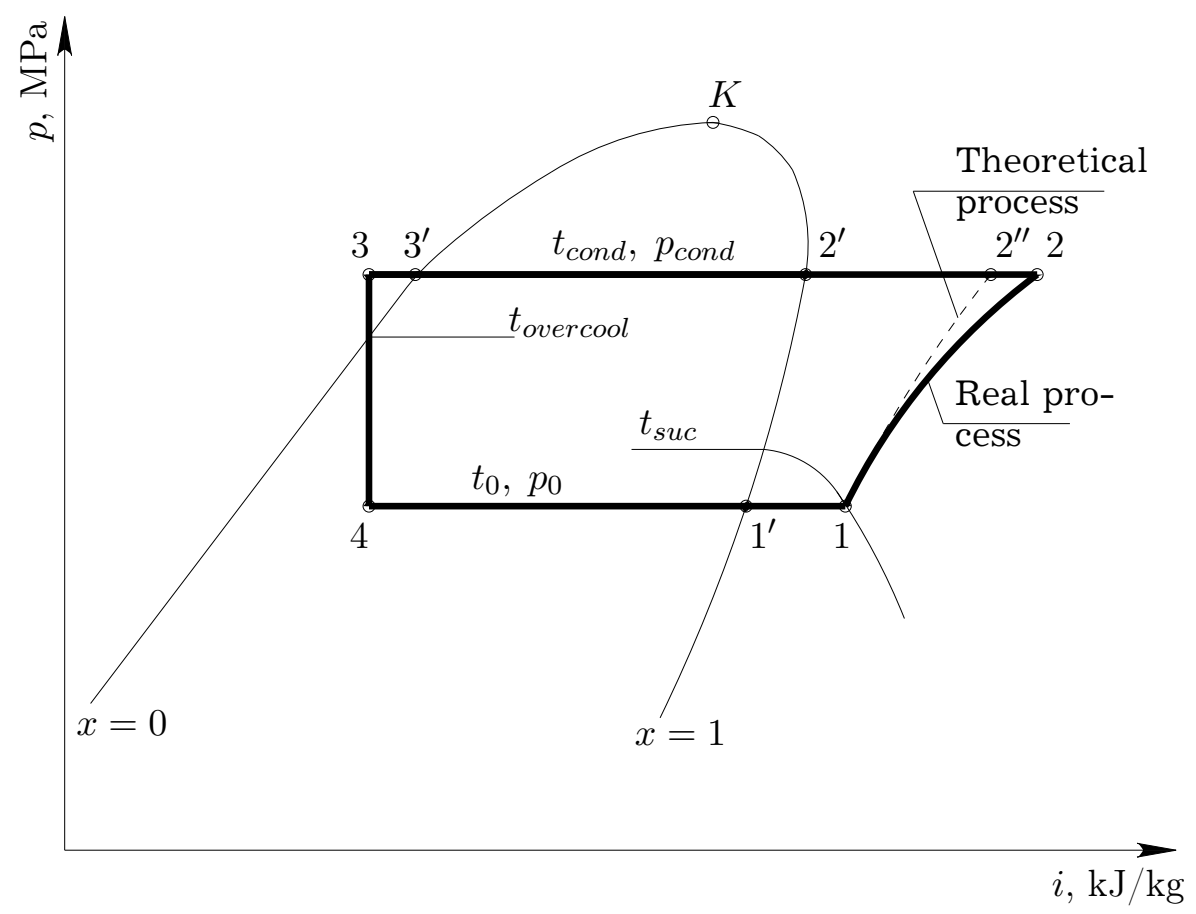

Fig. 2. Construction of the processes of work on $(p, i)$-diagram for heat pump of air split-conditioner: $1,2,3,4$ are characteristic points of the thermodynamic cycle.

Construction on $(p, i)$-diagram of the process of work of the heat pump of air split-conditioner is shown in Fig. 2.

Note the processes that characterize the cut-offs that are obtained on the $(p, i)$-diagram (Fig. 2):

- $1-2^{\prime \prime}$ is theoretical (adiabatic $s_{1}=$ const) compression in the compressor of dry overheated steam of the RA from the evaporation pressure $p_{e v}=p_{1}$ to the condensation pressure $p_{\text {cond }}=p_{2^{\prime \prime}}$. 
- $1-2$ is real (polytropic) compression in the compressor of dry overheated steam of the RA from the evaporation pressure $p_{e v}=p_{1}$ to the condensation pressure $p_{\text {cond }}=p_{2}$.

- $2-2^{\prime}$ is isobaric cooling ( $p_{\text {cond }}=$ const) of overheated steam of the RA in the condenser from the temperature $t_{2}$ to the temperature of condensation (saturation) $t_{c o n d}=t_{2^{\prime}}$ due to removal of heat by internal (recirculation) air from a room.

- $2^{\prime}-3^{\prime}$ is isobaric-isothermal $\left(p_{\text {cond }}=\right.$ const, $t_{\text {cond }}=$ const $)$ condensation of steam of the RA in the condenser due to removal of heat by internal (recirculation) air from a room.

- $3^{\prime}-3$ is isobaric overcooling $\left(p_{\text {cond }}=\right.$ const) of the liquid refrigerant in the condenser from the condensation temperature $t_{\text {cond }}=t_{3^{\prime}}$ to the overcooling temperature $t_{\text {overcool }}=t_{3}$ due to removal of heat by internal (recirculation) air from a room.

- $3-4$ is isoenthalpic $\left(i_{3}=\right.$ const) throttling of the liquid refrigerant in the capillary tube with a decrease in pressure from $p_{\text {cond }}=p_{3}$ to $p_{e v}=p_{4}$.

- $4-1^{\prime}$ is isobaric-isothermal ( $p_{e v}=$ const, $t_{e v}=$ const) evaporation of the liquid RA in the evaporator due to the heat supply from cooling external air (environment).

- $1^{\prime}-1$ is isobaric $\left(p_{e v}=\right.$ const) overheating of the RA steam in the evaporator from the evaporation temperature $t_{e v}=t_{1^{\prime}}$ to the suction temperature $t_{s u c}=t_{1}$ due to the heat supply from cooling external air (environment).

Overcooling of the refrigerant (line $3^{\prime}-3$ ) compensates losses during throttling and increases heating capacity of the air conditioner. Some overheating of vapor of the RA before suction in a compressor (line $1^{\prime}-1$ ) provides the "dry" course of the compressor.

Then find the parameters of the working refrigeration agent in the characteristic points of the scheme of air split-conditioner heat pump or by using the thermodynamic $(p, i)$-diagram of RA or by using its tables $[19,20]$ or according to the formulas obtained by the authors on the basis of the tables for the corresponding RA (R410A) and valid in the temperature range $0 \ldots 50^{\circ} \mathrm{C}$.

For calculating the exergetic OIR and analysis of work of heat pump of air split-conditioner, the following output data are necessary to have:

- standard heating capacity of air split-conditioner $Q_{H}^{s t}, \mathrm{~W}$;

- the temperature of outside air at the enter $t_{C 1}=+7^{\circ} \mathrm{C}$ in the evaporator and the inflow one at the exit $t_{C 2}$ from it;

- the internal air temperature at the enter $t_{H 1}=+21^{\circ} \mathrm{C}$ and at the exit $t_{H 2}$ from the condenser;

- thermodynamic properties of RA - refrigerant R410A;

- scheme of the heat pump unit (Fig. 1).

Initially, the evaporation and condensation temperatures were calculated at standard external temperature conditions for the evaporator, when the external (environment) air which is cooled in the evaporator of the air split-conditioner has an initial temperature $t_{C 1}=+7^{\circ} \mathrm{C}$ and for a condenser, when the internal (recirculation) air of room by which the air split-conditioner condenser is cooled by has an initial temperature of $t_{H 1}=+21^{\circ} \mathrm{C}$, and the temperature of the suction of a steam of the refrigerant in the compressor and the overcooling of the liquid refrigerant in the condenser. Then the process of work of the heat pump without cooling the compressor in the thermodynamic corresponding $(p, i)$-diagram (Fig. 2) has been built. In the characteristic points of the scheme by the diagram or by tables or by formulas, the parameters of the refrigerant have been finding $[19,20]$.

By thermodynamic $(p, i)$-diagram, the heat consumption per unit cost of the working refrigeration agent in separate units of the heat pump of the air split-conditioner have been finding.

Specific internal indicator work of the compressor of the air split-conditioner is:

$$
l_{i}=i_{2}-i_{1}, \quad \mathrm{~kJ} / \mathrm{kg},
$$

where $i_{1}$ and $i_{2}$ are the specific enthalpy at the corresponding points of the heating cycle of heat pump, $\mathrm{kJ} / \mathrm{kg}$. 
Then find the heating ratio of the heat pump of the air split-conditioner according to the formula:

$$
\mu=\eta_{\text {em }} q_{\text {cond }} / l_{i}
$$

where $\eta_{e m}$ is the electromechanical OIR of the compressor $\left(\eta_{e m}=0.9\right) ; q_{c o n d}=i_{2}-i_{3}, \mathrm{~kJ} / \mathrm{kg}$, is specific heat consumption in the condenser per unit cost of the refrigerant.

The exergetic OIR of the heat pump of the air split-conditioner have founded by the formula:

$$
\eta_{e}=E_{H} \cdot \mu
$$

where $E_{H}=T_{e n v} / \bar{T}_{H}-1$ is specific consumption of electric energy (exergy) in the ideal cycle, that is attributed to the unit of heat removed from the heat sink (condenser) with the average temperature $\bar{T}_{H}, \mathrm{~K} ; T_{e n v}$ is environmental temperature, $\mathrm{K}$.

The value of exergy of the refrigerant in the characteristic points of the process of heat pump have determined by the formula:

$$
e=i-i_{e n v}-T_{e n v}\left(s-s_{e n v}\right), \quad \mathrm{kJ} / \mathrm{kg},
$$

where $i$ is the value of the specific enthalpy of the refrigerant in the characteristic points of the process, $\mathrm{kJ} / \mathrm{kg} ; i_{\text {env }}$ is the value of the specific enthalpy of the refrigerant in the state $T_{\text {env }}, p_{\text {env }}$ (temperature and pressure of the environment), which is in equilibrium with the environment, $\mathrm{kJ} / \mathrm{kg}$; $s$ and $s_{e n v}$ are corresponding values of the refrigerant entropy, $\mathrm{kJ} /(\mathrm{kg} \cdot \mathrm{K})$, which have been determined by thermodynamic tables or diagrams or formulas [19,20].

Then find the specific amount of exergy which is inputted into the heat pump of the air splitconditioner in the form of electric energy that is brought to the electric motor of compressor, using the formula:

$$
e_{i n}=N_{i n} \cdot 10^{-3} / G, \quad \mathrm{~kJ} / \mathrm{kg},
$$

where $N_{i n}$ is the power consumed by the electric motor of the compressor, W; $G=Q_{H} \cdot 10^{-3} / q_{\text {cond }}$ is quantity of circulating refrigeration agent in the contour of heat pump, $\mathrm{kg} / \mathrm{s}$.

The losses of exergy in some apparatus of the heat pump of the air split-conditioner is:

$$
d=e_{\text {beg }}-e_{\text {end }}, \quad \mathrm{kJ} / \mathrm{kg},
$$

or as a percentage of the exergy that is entered into the heat pump:

$$
D=\left(e_{\text {beg }}-e_{\text {end }}\right) \cdot 100 / e_{\text {in }}, \quad \%,
$$

where $e_{b e g}$ and $e_{\text {end }}$ are value of the specific exergy of the refrigerant in the beginning and at the end of the process in a separate apparatus of the heat pump of air split-conditioner, $\mathrm{kJ} / \mathrm{kg}$.

The exegetic balance of the one-stage steam-compressor heat pump (without effective cooling of compressor) of the air split-conditioner for $1 \mathrm{~kg} / \mathrm{s}$ of the flow of a circulating working refrigerant has the form [16-18]:

$$
e_{\text {in }}=e_{\text {out }}+\Sigma d, \quad \mathrm{~kJ} / \mathrm{kg}
$$

or as a percentage of $e_{i n}$

$$
E_{\text {in }}=E_{\text {out }}+\Sigma D, \quad \%
$$

where $e_{\text {in }}$ is the quantity of the specific exergy, that enters into heat pump of conditioner, $\mathrm{kJ} / \mathrm{kg} ; e_{\text {out }}$ is the quantity of the specific exergy, which comes out from the heat pump of the conditioner, $\mathrm{kJ} / \mathrm{kg}$; $\Sigma d$ is total losses of specific exergy in all apparatuses of the heat pump of the conditioner, $\mathrm{kJ} / \mathrm{kg}$; $E_{\text {in }}, E_{\text {out }}, \Sigma D$ are respectively, exergy of the heat pump of air split-conditioner, which is spent on maintaining the process of its work; the increase of exergy of air in the heated room; total losses of 
exergy in all apparatuses of the heat pump of the air conditioner as a percentage (\%) of the exergy $e_{i n}$, which is included in the heat pump.

Losses of exergy in the heat pump of the air conditioner consists of losses of exergy in the compressor, due to the irreversible heat transfer in the condenser, the capillary tube (throttle) and the losses of exergy in the evaporator, i.e.

$$
\begin{gathered}
\Sigma d=d_{\text {compr }}+d_{\text {cond }}^{\text {irrev.h.tr }}+d_{t h r}+d_{e v}, \quad \mathrm{~kJ} / \mathrm{kg}, \\
\Sigma D=D_{\text {compr }}+D_{\text {cond }}^{\text {irrev.tr }}+D_{t h r}+D_{e v}, \quad \%,
\end{gathered}
$$

where $D_{\text {compr }}, D_{\text {cond }}^{\text {irrev.h.tr }}, D_{t h r}, D_{\text {ev }}$ are respectively, losses of exergy in the compressor, the condenser, the capillary tube and the evaporator, $\%$.

The exergetic balance of this heat pump of the air split-conditioner based on its principal scheme (Fig. 1).

Obviously, the perfection of the heat pump of the air split-conditioner and its elements is that higher, the higher the exergetic OIR is, which was also determined from the exergetic balance, namely $[7,8$, 16-18]:

$$
\eta_{e}=E_{\text {out }} / E_{\text {in }}
$$

Calculation of the exergetic OIR of the heat pump of the air split-conditioner creates conditions for solving the issue of saving fuel and energy resources [7,8,16-18].

Consequently, the exergetic OIR of the heat pump of the air split-conditioner also have been calculated by the formula (12), in which the numerator is a useful exergetic effect, and the denominator is the cost of exergy.

We have calculated the exergetic OIR of the one-stage heat pump of air split-conditioner of firm "Daikin" with nominal heating capacity $Q_{H}^{s t}=2500,2840,3580,5620,6400 \mathrm{~W}$ at standard temperature conditions on refrigerant R410A. For the calculation were accepted:

- overcooling of the liquid refrigerant in the condenser $\Delta t_{\text {overcool }}=5^{\circ} \mathrm{C}$;

- overheating of the refrigerant vapor in the evaporator $\Delta t_{\text {overheat }}=10^{\circ} \mathrm{C}$;

- final temperature difference in the evaporator (external air and boiled refrigeration agent) $\Delta t_{e v}=$ $2.8^{\circ} \mathrm{C}$;

- final temperature difference in the condenser (internal air from the room and condensing refrigerant) $\Delta t_{\text {cond }}=4.2^{\circ} \mathrm{C}$.

For calculations on the computer mathematical model the $(p, i)$-diagram of the refrigerant R410A in the temperature range $0 \ldots 50^{\circ} \mathrm{C}$ was fed as analytical dependences $p=f(t), i=\varphi(t), s=\psi(t)$.

The calculation results are summarized in Table 1.

Table 1. Results of calculating of exergetic OIR and losses of exergy in the air split-conditioner heat pump elements of firm "Daikin".

\begin{tabular}{|c|c|c|c|c|c|}
\hline \multirow{2}{*}{$\begin{array}{c}\text { Standard heating } \\
\text { capacity of heat pump } \\
Q_{H}^{\text {st }}, \mathrm{W}\end{array}$} & \multicolumn{4}{|c|}{ Losses of exergy in the air } & \multirow{2}{*}{ Exergetic } \\
\cline { 2 - 5 } & $D_{\text {compr }}$ & $D_{\text {cond }}^{\text {irrev.h.tr }}$ & $D_{\text {thr }}$ & $D_{e v}$ & \\
\hline 2500 & 25.3 & 19.5 & 9.0 & 5.9 & 40.2 \\
\hline 2840 & 25.3 & 18.9 & 8.6 & 8.3 & 39.0 \\
\hline 3580 & 25.3 & 17.8 & 7.9 & 11.5 & 37.4 \\
\hline 5620 & 25.3 & 16.4 & 7.1 & 15.2 & 35.9 \\
\hline 6400 & 25.3 & 16.0 & 6.9 & 16.7 & 35.1 \\
\hline
\end{tabular}

The maximum reduction of the exergetic OIR due to the increase in heat capacity of air splitconditioners heat pumps is:

$$
\Delta=\frac{40.2-35.1}{40.2} \cdot 100=12.9 \% \text {. }
$$




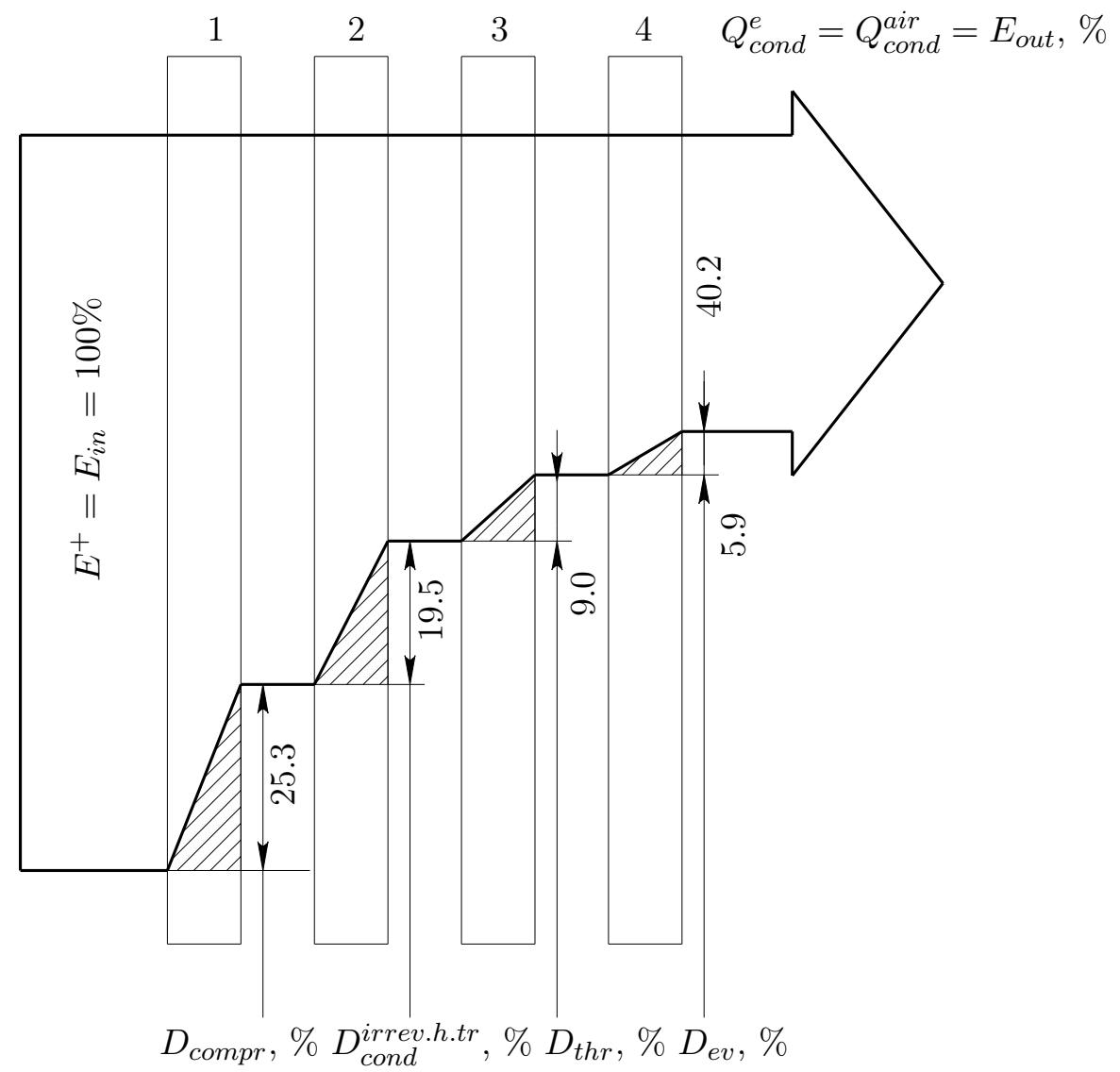

Fig. 3. The Grassmann's diagram of the exergetic flows of the heat pump of the air splitconditioner: $D_{\text {compr }}, D_{\text {cond }}^{\text {irrev.h.tr }}, D_{t h r}, D_{e v}$ are respectively, losses of exergy in the compressor, the condenser, the capillary tube and the evaporator, \%.

According to the results of calculation, the Grassmann's diagrams of the exergetic flows of the heat pumps of the air split-conditioners have been built (for example, in Fig. 3 it is shown for an air splitconditioner heat pump with a standard heat capacity of $2500 \mathrm{~W}$ ).

\section{Conclusions}

The author's innovative mathematical model for exergetic analysis of the operation of one-stage heat pumps of the air split-conditioners, used in local autonomous air conditioners to create comfortable conditions in the premises of buildings in the cold season, has been developed. The experiments have been conducted on the basis of the mathematical model to establish the exergetic OIR and losses of exergy in separate elements of heat pumps of air split-conditioners on the example of air conditioners with nominal heat capacity 2500, 2840, 3580, 5620, $6400 \mathrm{~W}$ of "Daikin" firm under standard external temperature conditions for refrigerant R410A.

It has been determined that with exergetic OIR, air split-conditioners heat pumps with higher heat capacity have lower exergetic OIR. In our opinion, this is due to the incorrect acceptance of the air flow rates on the evaporator and condenser, which do not correspond to the heat balances of these apparatuses and the same internal temperature regime for different heat capacity of air splitconditioners heat pumps $[17,18]$. An example is a Grassmann's diagram for a $2500 \mathrm{~W}$ heat pump.

The losses of exergy having been revealed in all elements of air split-conditioners heat pumps indicate the fact that elements of the air split-conditioner must be improved for reducing losses of exergy in them and the overall increase of the exergetic OIR of heat pumps. 
The mathematical model of operation of air split-conditioners heat pumps can be applied to different types of refrigerants and split-conditioner models provided the thermodynamic properties of the refrigerant and the characteristics of the split-conditioner heat pump are known.

[1] Energy Strategy of Ukraine until 2030, http://www.ukrenergo energy .gov .ua (in Ukrainian).

[2] Heat Pump, Types and Applications of Heat Pumps, http://www. ecosvit.net/ua/teplovij-nasos-vidi-ta zastosuvannya (in Ukrainian).

[3] Heat pumps, http://www.npblog.com.ua/index.php/hi-tech/teplovi-nasosi.html (in Ukrainian).

[4] Bezrodnyi M. N., Dranik T. V. Thermodynamic Efficiency of Heat Pump Application for Providing Comfortable Conditions in Indoor Swimming Pools. Eastern European Journal of Enterprise Technologies. 3 (8), 25-30 (2013).

[5] Matsevityi Yu. M., Chirkin N. B., Bogdanovich A. S., Klepanda A. S. Introduction of Heat Pumping Technologies. Ecotechnology and Resource Saving. 3, 4-10 (2008), (in Russian).

[6] Zalewski P. K. Pompy ciepła. Podstawy teoretyczne i przykiady zastosowania. Kraków (1995), (in Polish).

[7] Szargut J., Petela R. Exergy. Moscow, Energy (1968), (in Russian).

[8] Sokolov E. Y., Brodyansky V. M. Energy Basis of Transformation of Heat and Cooling Processes. Moscow, Energoizdat (1981), (in Russian).

[9] Morozyuk T. V. Theory of Refrigeration Machines and Heat Pumps. Odessa, Studio "Negotsiant" (2006), (in Russian).

[10] Silvio de Oliveira Jr. Exergy. Production, Cost and Renewability. Springer (2013).

[11] Sazhin B. S., Bulekov A. P., Sazhin B. S. Exergy Analysis of Work of Industrial Plants. Moscow (2000), (in Russian).

[12] Bejan A. Advanced Engineering Thermodynamics. New York, John Wiley \& Sons (1988).

[13] Bejan A., Tsatsaronis G., Moran M. Thermal Design and Optimization. New York, J. Wiley (1996).

[14] Morosuk T., Nikulshin R., Morosuk L. Entropy-Cycle Method for Analysis of Refrigeration Machine and Heat Pump Cycles. Thermal Science. 10 (1), 111-124 (2006).

[15] Tsatsaronis J. The Interaction of Thermodynamics and Economy to Minimize Cost of Energy Conversion Systems. Odessa, Studio "Negotsiant" (2002), (in Russian).

[16] Labay V., Dovbush O., Yaroslav V., Klymenko H. Mathematical Modeling of a Split-conditioner Operation for Evaluation of Exergy Efficiency of the R600A Refrigerant Application. Mathematical Modeling and Computing. 5 (2), 169-177 (2018).

[17] Labay V. Yo., Khanyk Ya. M. Energy Saving Ratio Between the Air Flows at the Evaporator and Condenser Air Split-conditioners. Refrigeration Engineering and Technology. 6 (116), 28-31 (2008), (in Ukrainian).

[18] Labay V. Yo., Mysak Yo. S. Adduction of Work of Refrigeration's Machines of Air Split-conditioners to the Identical Internal Temperature Condition. Refrigeration Engineering and Technology. 4 (126), 19-22 (2010), (in Ukrainian).

[19] Jakobsen A., Rassmussen B.-D., Skovrup M.-J., Andersen S.-E. CoolPack - a collection of simulation tools for refrigeration systemes. Tutorial. Version 1.46. Department of Energy Engineering Technical University of Denmark (2001).

[20] Daikin Catalog Split (2017). 


\title{
Математичне моделювання роботи теплової помпи спліт-кондиціонера для дослідження її ексергетичної ефективності
}

\author{
Лабай В. Й., Ярослав В. Ю., Довбуш О. М., Цізда А. Є. \\ Кафедра теплогазопостачання $і$ вентиляиї, \\ Інститут будівництва та інженерних систем, \\ Національний університет "Львівсъка політехніка", \\ вул. С. Бандери, 12, 79013, Львів, Україна
}

У сучасних технологіях, пов'язаних з перетворенням енергії, а саме в теплових помпах split-кондиціонерів ("повітря-повітря"), важливе місце займають апарати та процеси, об'єктивна оцінка ступеня їх енергетичної досконалості може бути визначена лише на основі аналізу їх ексергетичної ефективності. Це дозволило обгрунтувати актуальність дослідницького завдання, що пов'язано з недостатньою інформацією щодо ексергетичної ефективності використання теплових помп split-кондиціонерів та їх елементів. Розроблено авторську інноваційну математичну модель для аналізу роботи одноступеневих фреонових теплових помп, які використовуються у splitкондиціонерах, за ексергетичним методом. В статті проаналізовано ексергетичний коефіцієнт корисної дії (ККД) та втрати ексергії в окремих елементах теплових помп split-кондиціонерів на прикладі кондиціонерів з номінальною теплопродуктивністю 2500, 2840, 3580, 5620, 6400 Вт фірми "Daikin" за стандартних зовнішніх температурних умов на холодоагенті R410A. Було визначено, що за ексергетичним KKД теплові помпи split-кондиціонерів, що мають вищу теплопродуктивність, володіють нижчим ексергетичним ККД. На нашу думку це пов'язано з некоректним прийняттям витрат повітря на випарнику і конденсаторі, які не відповідають тепловим балансам цих апаратів та однаковому внутрішньому температурному режимові для різних теплопродуктивностей теплових помп split-кондиціонерів. Для прикладу наведена діаграма Грассмана теплової помпи з теплопродуктивністю 2500 Вт. Втрати ексергії, встановлені в усіх елементах теплових помп split-кондиціонерів, вказують на необхідність удосконалення обладнання split-кондиціонера, щоб зменшити втрати ексергії в них та загалом збільшити його ексергетичний ККД.

Ключові слова: теплова помпа split-кондиціонера, ексергетичний баланс, ексергетичний ККД, втрати ексергї. 